\title{
PENGARUH AKLIMATISASI KADAR GARAM TERHADAP NILAI KEMATIAN DAN TINGKAH LAKU IKAN GUPPY (POECILIA RETICULATA) SEBAGAI PENGGANTI UMPAN IKAN CAKALANG (Katsuwonus Pelamis)
}

\section{(THE IMPACT OF ACCLIMATIZATION OF VARIOUS SALINITY TO AGAINTS MORTALITAS RATE AND BEHAVIOUR FISH GUPPY (POECILIA RETICULATA) AS A SUBTITUTE FOR FISH BAIT SKIPJACK (KatsuwonusPelamis))}

\author{
Muhammad Zainuddin Lubis ${ }^{1,2}$ dan Sri Pujiyati ${ }^{2}$ \\ ${ }^{1}$ Corresponding author \\ ${ }^{2}$ Depertemen Ilmu dan Teknologi Kelautan \\ Fakultas Perikanan dan Ilmu Kelautan, Institut Pertanian Bogor \\ Email: lubiszainuddin@gmail.com
}

\begin{abstract}
Acclimatization is physiological adaptation way or a way from a species to adjust itself with new environment. The

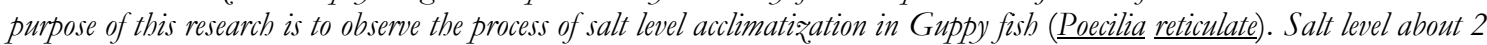
$\mathrm{g} / \mathrm{mol}$ was added in the water or environment until the salinity is $30 \%$. Guppy fish males have a body size $5 \mathrm{~cm}$, colour schemes the body and fins are very bright and has a very economical price so as to attract the attention of Tuna (Katsuwonus pelamis). That process was done by adding $720 \mathrm{~g}$ of salt level each day during 14 days. In the first day, 65 Guppy fishes with average of weight is 1,1 gram and total length is 2,5 cm was added in the water. During 8 days (salinity $18 \%$ ), Guppy fish can adjust itself with the environmental, however after 8 days mortality rate of the fish is 0,02\%-0,05\%. Until the end of the research, the mortality rate is 0,13\% (9 fishes). Fish test results conducted in the waters of Pramuka Island, thousand islands, showed fish can swim well and always be in the surface waters without sight change very significant.
\end{abstract}

Keywords: Acclimatization, Guppy fish (Poecilia reticulata), salt level, mortality rate, fish behaviour

\begin{abstract}
ABSTRAK
Aklimatisasi merupakan suatu upaya penyesuaian fisiologis atau adaptasi dari suatu organisme terhadap suatu lingkungan baru yang akan dimasukinya. Penelitian ini mengamati proses aklimatisasi kadar garam pada ikan guppy (Poecilia reticulata). Proses aklimatisasi kadar garam pada ikan Guppy yang dilakukan selama 14 hari dengan menaikkan 720 gram per hari. Kadar garam terukur adalah 30\%. Ikan Guppy (Poecilia reticulata) memiliki ukuran tubuh $\pm 5 \mathrm{~cm}$, corak warna tubuh dan sirip yang sangat cemerlang dan memiliki harga yang sangat ekonomis sehingga dapat menarik perhatian Ikan Cakalang (Katsuwonus pelamis). Awal proses aklimatisasi ikan Guppy berjumlah 65 ekor dengan berat rata-rata 1,1 gram dan panjang total yaitu 2,5 cm. Selama 8 hari pengamatan (18\%), ikan mampu beradaptasi dengan lingkungannya, namun setelah hari ke 8 ikan ada yang mengalami kematian $0,02 \%-0,05 \%$, namun secara total sampai akhir pengamatan, kematian ikan relatif lebih kecil yaitu 0,13\% (9 ekor). Hasil uji coba ikan yang dilakukan pada perairan Pulau Pramuka Kepulauan Seribu menunjukkan ikan dapat berenang dengan baik dan selalu berada di permukaan air tanpa perubahan yang terlihat yang sangat signifikan.
\end{abstract}

Kata kunci: Aklimatisasi, Ikan Guppy (Poecilia reticulata), kadar garam, kematian, tingkah laku ikan

\section{PENDAhUluaN}

Aklimatisasi merupakan suatu upaya penyesuaian fisiologis atau adaptasi dari suatu organisme terhadap suatu lingkungan baru yang akan dimasukinya. Hal ini didasarkan pada kemampuan organisme untuk dapat mengatur morfologi (Hazarika, 2003). Keberhasilan proses aklimatisasi pada ikan Guppy akan menjadi terobosan terbaru dalam diservifikasi umpan ikan Cakalang (Katsuwonus pelamis). Menurut Subani dan Barus (1989), makanan ikan cakalang adalah ikan teri, sardin, selar, kembung, dan lolosi. Ikan cakalang sangat suka dengan warna yang sangat menonjol pada ikan, dengan demikian umpan alternatif sebaiknya dibuat menyerupai ciri-ciri umpan ikan tersebut.

Ikan Guppy (Poecilia reticulata) merupakan salah satu komoditas jenis 
ikan hias air tawar yang populer dan banyak diminati oleh masyarakat terutama ikan Guppy jantan. Ikan Guppy jantan lebih disukai dibandingkan ikan Guppy betina karena Guppy jantan memiliki sirip ekor yang lebar dengan corak warna bervariasi dan memiliki warna merah yang sangat menonjol dibandingkan dengan ikan Guppy betina (Kwon et al, 2000). Ikan Guppy (Poecilia reticulata) jantan memiliki corak warna tubuh dan sirip yang sangat cemerlang dan memiliki harga yang sangat ekonomis dibandingkan dengan ikan hias lainnya (Arfah, 1997); (Suwarsito et al, 2003)

Ikan Guppy (Poecilia reticulata) adalah ikan berukuran kecil yang memiliki masa kehamilan dalam jangka waktu pendek. Masa kehamilan ikan ini berkisar antara 21-30 hari (rata-rata 28 hari) bergantung pada suhu airnya. Suhu air yang paling cocok untuk berbiak adalah sekitar $27^{\circ} \mathrm{C}\left(72{ }^{\circ} \mathrm{F}\right)$. Ikan Guppy (Poecilia reticulata) di akuarium dapat mencapai panjang $6 \mathrm{~cm}$, namun di alam kebanyakan hanya tumbuh hingga sekitar $3 \mathrm{~cm}$ saja. Ukuran ini terlalu kecil untuk memangsa jentik-jentik nyamuk. Saat ikan ini dapat ditemukan di berbagai tempat di Nusantara dan mungkin telah menjadi ikan yang paling melimpah di Jawa dan Bali (Wirjoatmodjo, 1993). Gambar 1 adalah induk ikan Guppy (Poecilia reticulata) yang digunakan saat penelitian.

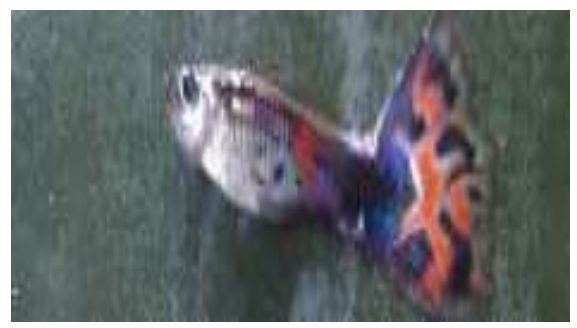

Gambar 1. Guppy (Poecilia reticulata)

Sullivan (1994) merangkumkan temuan-temuan berbagai peneliti tentang dampak temperatur dan kadar garam pada distribusi ikan, dan membahas peranan mekanisme reseptor sistem syaraf pusat dalam reaksi temperatur dan kadar garam. Ia menyatakan bahwa ikan memilih temperatur dan kadar garam tertentu karena efek yang sama pada gerakan (aktivitas) mereka, dan menyimpulkan bahwa perubahan tempe- ratur dan kadar garam biasa bekerja pada ikan:

1. Sebagai stimulus syaraf,

2. Modifikator proses metabolisme, dan atau,

3. Modifikator aktivitas tubuh.

\subsection{Tujuan Penelitian}

Tujuan dari kegiatan penelitian ini adalah sebagai berikut:

1. Aklimatisasi salinitas ikan Guppy (Poecilia reticulata).

2. Mengamati tingkah laku ikan Guppy (Poecilia reticulata) selama proses aklimatisasi.

\subsection{Manfaat Penelitian}

Penelitian ini diharapkan dapat menjadi alternatif diversifikasi umpan ikan Cakalang (Katsuwonus pelamis), yang sampai saat ini umpan ikan Cakalang terhitung mahal dan sulit atau sedikit ketersediannya.

\section{METODE PENELITIAN}

Kegiatan penelitian dan pengolahan data dilaksanakan dari tanggal 14 Mei hingga 30 Juni 2013. Kegiatan pengamatan gerak ikan saat proses aklimatisasi dilaksanakan di laboratorium Akustik Instrumentasi Kelautan (AIK) yang bertempat di water tank. Kegiatan pengambilan dan perekaman data dilaksanakan selama dua minggu yakni dari tanggal 20 Juni 2013 hingga 24 Juni 2013. Pelepasan ikan di perairan laut dilaksanakan tanggal 26 Juni 2013 di pulau Pramuka Kepulauan Seribu.

\subsection{Alat dan Bahan}

Alat yang digunakan adalah akuarium berukuran panjang $40 \mathrm{~cm}$, lebar 30 $\mathrm{cm}$, dan tinggi $30 \mathrm{~cm}$, yang berfungsi sebagai tempat pengamatan: aerator untuk membantu proses sirkulasi oksigen dalam akuarium; refraktometer untuk mengukur salinitas air yang ada didalam akuarium; refraktometer untuk mengukur suhu dan salinitas air di dalam akuarium.

Bahan yang digunakan adalah 65 ekor ikan Guppy (Poecilia reticulata), yang merupakan sebagai objek yang akan diamati, berukuran kecil dengan panjang $\pm 5 \mathrm{~cm}$; air tawar sebagai media hidup ikan dalam akuarium; garam laut yang digunakan untuk menambahkan 720 
gram garam pada wadah yang sudah ditentukan dengan cara mengaduk dengan menambahkan 2 liter air yang berasal dari akuarium penelitian. Melarutkan garam pada air yang diambil hingga benar-benar larut dengan air. Gambar 2 adalah diagram alir penelitian.

\subsection{Proses Pemilihan dan Aklimatisasi Ikan Dalam Akuarium Pemeliha- raan}

Ikan Guppy (Poecilia reticulata) yang terpilih adalah ikan yang sehat dengan tanda-tanda yaitu: gesit, dan lincah. Ikan dipelihara dalam akuarium pemeliharaan sementara sebelum dipindahkan ke akuarium pengamatan untuk proses adaptasi awal terhadap lingkungan sekitar manusia dan penyesuaian pakan berupa pelet tenggelam.

\subsection{Proses Pemindahan Ikan Ke Akua- rium Pengamatan}

Ikan yang terpilih dari akuarium pemeliharaan dimasukkan ke dalam kantung plastik dan dibawa menuju akuarium pengamatan.

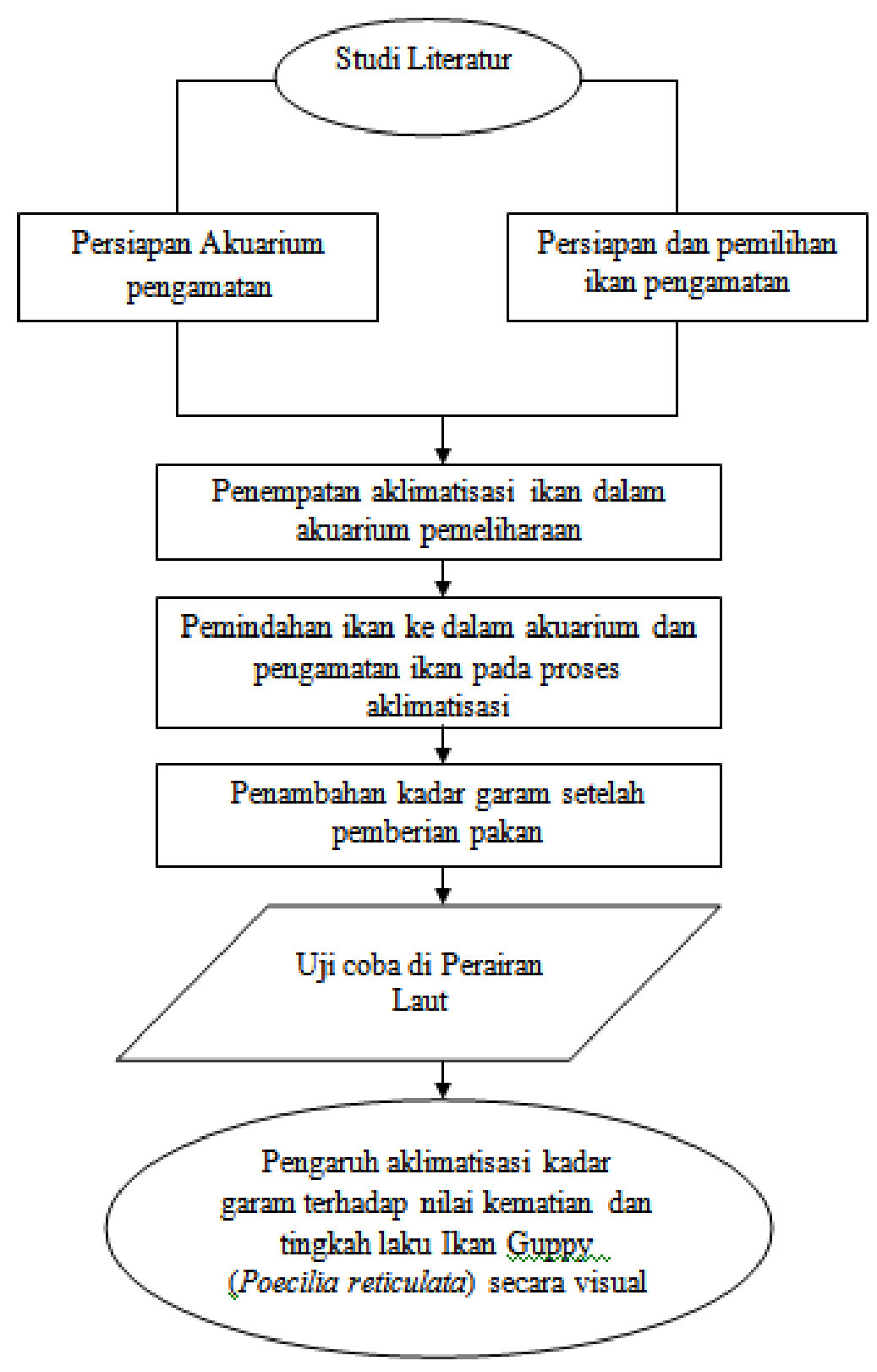

Gambar 2. Diagram alir penelitian 
Ikan beserta plastiknya yang telah dibuka dimasukkan perlahan-lahan ke dalam akuarium pengamatan dan dibiarkan beberapa saat untuk penyesuaian terhadap lingkungan tempat hidupnya yang baru. Ikan dibiarkan keluar dengan sendirinya dari dalam kantung plastik. Ikan tidak diberikan pakan selama $\pm 1-2$ hari, karena pada massa ini ikan masih dalam keadaan stress akibat belum beradaptasi dengan lingkungannya yang baru.

\subsection{Penambahan Kadar Garam Pada Ikan}

1. Sebelum memasukkan garam yang sudah larut pada air maka akan dilakukan pengurangan massa air, sebanyak total air yang akan dimasukkan ke dalam akuarium yaitu 2 liter air dengan 720 gram garam laut.

2. Penambahan kadar garam dilangsungkan sampai salinitas dari air tersebut mencapai salinitas 30\%.

3. Penambahan kadar garam pada ikan yang dilakukan di akuarium pengamatan dilakukan dengan rutin setiap harinya yaitu pada malam hari dengan tujuan agar data yang dihasilkan bagus.

4. Penambahan kadar garam laut dilakukan 1 hari sebanyak 1 kali penambahan dengan ikan yang sama setiap harinya.

\subsection{Parameter Lingkungan}

Parameter lingkungan yang diukur adalah suhu dan salinitas karena kedua parameter fisika ini merupakan faktor yang paling berpengaruh terhadap tingkat stress ikan. Stress yang dialami ikan dapat menyebabkan penyimpangan tingkah laku pada ikan.

Pengukuran suhu air dalam akuarium dilakukan dengan cara memasukkan termometer $\mathrm{Hg}$ kedalam akuarium. Sterilisasi pada termometer sebelum dimasukkan ke dalam air untuk memperkecil efek muainya dan mengembalikan titik awal termometer sebelum pengukuran dimulai. Suhu air diperoleh dengan membaca skala yang ditunjukkan pada thermometer Hg. Kontrol suhu air akuarium dilakukan pada malam hari saat sebelum dan sesudah penambahan garam laut 720 gram.

Salinitas diukur dengan cara meneteskan sampel air akuarium sebanyak satu tetes air ke atas permukaan kaca refraktometer lalu ditutup. Nilai salinitas didapat dengan membaca skala yang ditunjukkan pada teropong refraktometer. Kontrol salinitas air akuarium dilakukan pada malam hari saat sebelum dan sesudah penambahan garam laut 720 gram.

\subsection{Uji Coba Ikan di Air Laut}

Ikan yang sudah mengalami proses aklimatisasi selama 14 hari pada perairan laut tepatnya di Perairan Kepulauan Seribu, Pulau Pramuka. Ikan dilepas pada jaring yang memiliki ukuran $1 \mathrm{x} 1$ meter dan diamati dengan durasi selama 5 menit. Setelah uji coba, ikan tetap dibiarkan selama durasi 10-15 menit dengan tidak dilakukannya perekaman pergerakan ikan secara visual. Adapun uji coba ikan di air laut ini berguna sebagai tinjauan lapang agar penelitian dapat berhasil sesuai dengan keinginan.

\subsection{Pengamatan gerak ikan dengan cara visual}

Pengamatan ini dilakukan dengan menggunakan alat yaitu kamera. Kamera pengamatan berada di atas sisi kanan dari akuarium pengamatan agar pengamatan secara visual terlihat lebih jelas dan tidak kabur. Pengamatan ini dilangsungkan setiap harinya yaitu berdurasi 1 menit dengan waktu pengamatan yaitu pada malam hari setiap harinya. Pengamatan ini berfungsi untuk melihat jumlah kematian dan kelincahan ikan bergerak setiap harinya saat penambahan kadar garam yaitu sebesar 720 gram garam laut.

\section{HASIL DAN PEMBAHASAN}

Proses aklimatisasi kadar garam pada ikan Guppy yang dilakukan selama 14 hari dengan menaikkan salinitas sebesar $2 \%$ per hari. Awal proses aklimatisasi ikan Guppy berjumlah 65 ekor dengan berat rata-rata 1,1 gram dan panjang total yaitu $2,5 \mathrm{~cm}$. Selama 8 hari pengamatan $(18 \%)$, ikan mampu beradaptasi dengan lingkungannya, namun setelah hari ke 8 ikan ada yang mengalami kematian $0,02 \%-0,05 \%$, namun secara total sampai akhir pengamatan, kematian ikan relative lebih kecil yaitu 9 ekor $(0,13 \%)$. Pengamatan fisik ikan umumnya pada saat proses aklimatisasi ikan mengalami perubahan warna yaitu menjadi merah. Menurut (Brett, 1999), 
hal ini disebabkan adanya sistem metabolisme yang rusak pada ikan, dan hal seperti ini akan menyebabkan kematian pada ikan tersebut. Adapun faktor yang menyebabkan efek dari kematian yaitu faktor regulasi. Faktor regulasi untuk setiap ikan harus terkontrol yaitu dalam proses metabolisme ikan tersebut, jika sistem metabolisme ikan tersebut rusak maka warna kemerahan akan timbul di badan ikan tersebut dan lama kelamaan akan menyebabkan kematian. Total kematian pada ikan Guppy dengan salinitas dapat dilihat pada Tabel 1 .

Tabel 1 hubungan salinitas sebelum dan sesudah ditambahkan garam laut sebesar 720 gram dengan jumlah ikan hidup dan ikan yang mati jelas terlihat kematian lebih besar yaitu pada hari ke 10 dengan salinitas sebesar 20\% sebelum ditambahkan garam, dan sesudah ditambahkan garam yaitu sebesar $22 \mathrm{ppm}$. Hal ini disebabkan berkurangnya daya tahan tubuh ikan dan nafsu makan ikanpun menurun. Menurut (Brett, 1999), hal ini disebabkan adanya sistem metabolisme yang rusak pada ikan, yang akan menyebabkan kematian pada ikan tersebut. Adapun faktor yang menyebabkan efek dari kematian yaitu faktor regulasi. Faktor regulasi untuk setiap ikan harus terkontrol yaitu dalam proses metabolisme ikan tersebut, jika sistem metabolisme ikan tersebut rusak maka warna kemerahan akan timbul dibadan ikan tersebut dan lama kelamaan akan menyebabkan kematian. Berikut adalah grafik hubungan salinitas dengan jumlah ikan yang hidup dapat dilihat pada Gambar 3.

Gambar 3 diatas memperlihatkan bahwa jumlah ikan yang hidup pada salinitas dibawah 19\% masih memiliki jumlah yang sama yaitu 65 ekor ikan. Hasil akhir pada salinitas $30 \%$ hanya 55 ekor ikan Guppy yang hidup, hal ini menjelaskan bahwa ikan Guppy mampu beradaptasi dengan kondisi air laut sesuai hasil pengamatan lanjutan yang dilakukan di perairan Pulau Pramuka, Kepulauan Seribu.

\section{Tingkah Laku Ikan Dalam Akuarium dan Di Perairan Laut \\ Hasil perekaman Tingkah Laku} Ikan (TLI) dengan menggunakan kamera terlihat ikan secara dominan berada di permukaan setelah penambahan kadar garam laut sebesar 720 gram (Gambar 4).

Tabel 1. Salinitas dengan Jumlah Ikan selama 14 Hari

\begin{tabular}{ccccc}
\hline & \multicolumn{2}{c}{ Salinitas $(\mathrm{ppm})$} & \multicolumn{2}{c}{ Jumlah ikan (ekor) } \\
\cline { 2 - 5 } Hari ke & Sesudah & Sebelum & Hidup & Mati \\
\hline 1 & 4 & 2 & 65 & 0 \\
2 & 6 & 4 & 65 & 0 \\
3 & 8 & 6 & 65 & 0 \\
4 & 10 & 8 & 65 & 0 \\
5 & 12 & 10 & 65 & 0 \\
6 & 14 & 12 & 65 & 0 \\
7 & 16 & 14 & 65 & 0 \\
8 & 18 & 16 & 65 & 0 \\
9 & 20 & 18 & 64 & 1 \\
10 & 22 & 20 & 61 & 3 \\
11 & 24 & 22 & 60 & 1 \\
12 & 26 & 24 & 58 & 2 \\
13 & 28 & 26 & 57 & 1 \\
14 & 30 & 28 & 55 & 1 \\
\hline
\end{tabular}




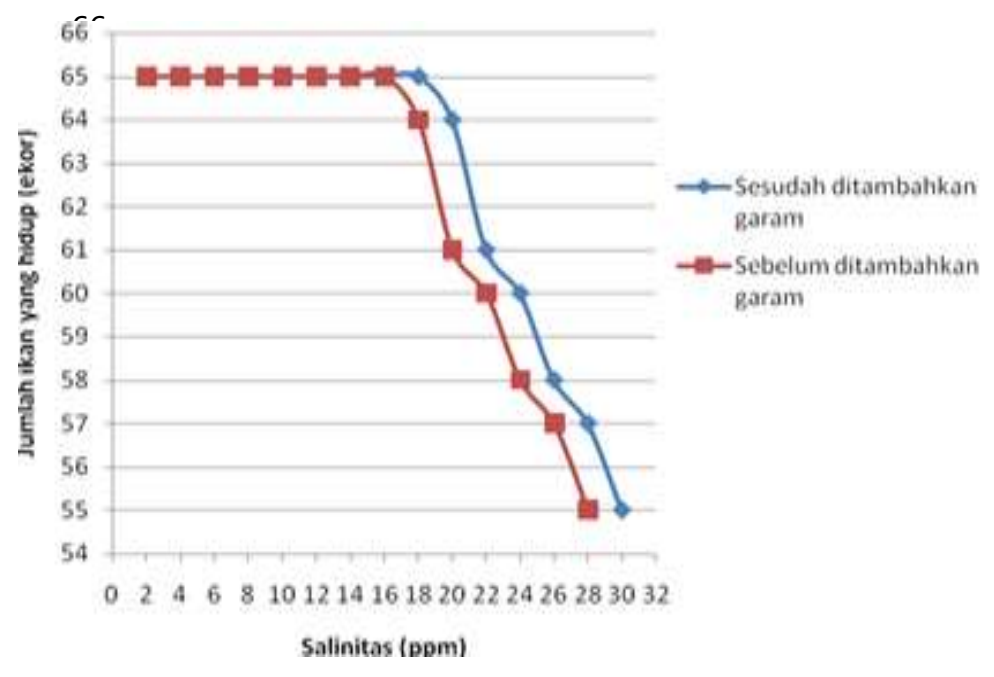

Gambar 3. Grafik Hubungan jumlah ikan yang hidup (ekor) dengan Salinitas (ppm)
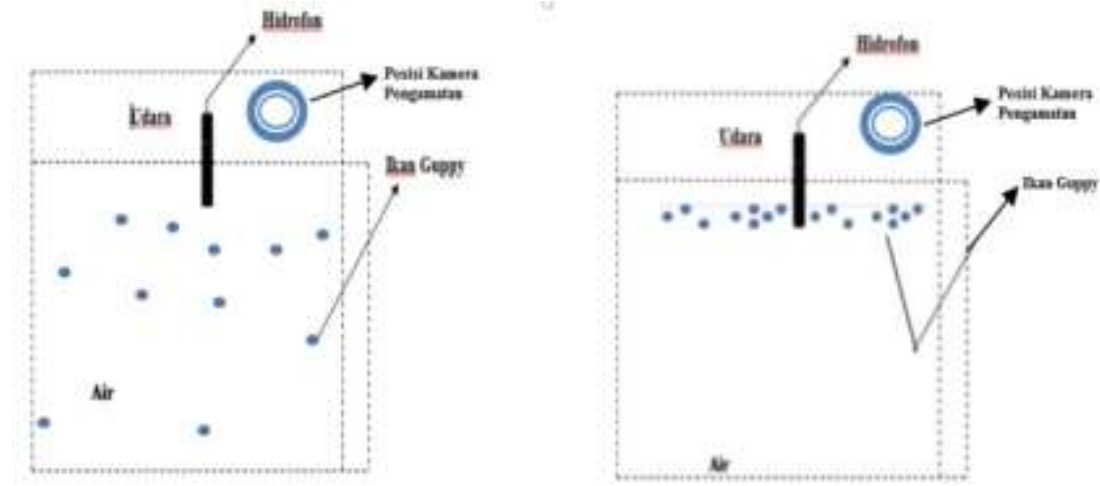

Gambar 4. Tingkah laku ikan sebelum ditambahkan garam (kiri), setelah ditambahkan garam (kanan)

Secara umum pada 14 hari dilakukan pengamatan, posisi ikan sebelum ditambahkan garam laut 720 gram terlihat menyebar karena tidak ada salinitas yang tinggi pada saat itu. Posisi ikan sesudah ditambahkan garam 720 gram berkumpul di permukaan karena adanya ancaman yaitu dengan bertambahnya salinitas. Pergerakan ikan pada saat setelah ditambahkan garam terlihat lebih agresif dan gesit dikarenakan suatu lingkungan berubah yaitu dengan naiknya Salinitas sebesar $2 \%$ setiap harinya.

Hasil uji coba ikan yang dilakukan pada perairan Pulau Pramuka, Kepulauan Seribu, menunjukkan ikan dapat berenang dengan baik dan selalu berada di permukaan perairan tanpa terlihat adanya perubahan yang sangat signifikan.

\section{KESIMPULAN}

Ikan Guppy (Poecilia reticulata) mampu hidup di air laut dengan proses aklimatisasi selama 14 hari. Ditambah kadar garam laut sebesar 720 gram hingga hari ke-14 dengan perubahan salinitas hingga $30 \%$. Pengujian di lapangan yaitu di Pulau Pramuka Kepulauan Seribu dapat dikatakan berhasil, karena ikan mampu bertahan 5-10 menit. Hal ini memberikan rekomendasi bahwa ikan Guppy dapat dimanfaatkan sebagai diversifikasi umpan ikan Cakalang (Katsuwonus pelamis). 


\section{DAFTAR PUSTAKA}

Arfah, H. 1997. Efektivitas Hormon 17a-Metiltestoteron dengan Metode Perendaman Induk terhadap Nisbah Kelamin dan Fertilitas Keturunan pada Ikan Guppy (Poecilia reticulata Peters). [Tesis]. Program Studi Pascasarjana Institut Pertanian Bogor. 42 lembar.

Brett, J. R. 1999. Environmental Factors and Growth. p. 599-675. In: W. S. Hoar,D. J. Randall and J. R Brett (editors), Fish Physiology. Vol. VIII, AcademicPress, New York.

Hazarika BN. 2003. Acclimatization of tissue-cultured plants. Curr Sci 85(12):1704-12.

Kwon, J.Y., V. Haghpanah, L.M.K. Hurtado, B.J. McAndrew dan D.J. Penman. 2000. Macculinization of genetic male Poecilia reticulata by dietary administration of an aromatase inhibitor during sexual differentiation. $J$ of Ex Zoo 287:4862.

Subani W dan HR. Barus. 1989. Alat Penangkap Ikan Dan Udang Laut Di Indonesia (Fishing Gears for marine Fish and Shrimp in Indonesia). No.50 Tahun 1998/1989. Edisi khusus. JPPL. Balai Penelitian Perikanan Laut. Badan Penilitian dan Pengembangan Pertanian Departemen Pertanian. Jakarta. 248 hal.

Sullivan, H. S. (1994). The psychiatric interview. New York: Norton. York.

Suwarsito, Syarifuddin, H., Mulia, D.S. 2003. Pengaruh Penambahan Methyltestoteron Dalam Pakan Terhadap Nisbah Kelamin Ikan Guppy (Poecilia reticulata Peters). $J$ Sains A, Fakultas Perikanan dan Ilmu Kelautan Universitas Muhammadiyah Purwokerto. 10 (1): 20-27.

Wirjoatmodjo. 1993. Ikan Air Tawar Indonesia Bagian Barat dan Sulawesi. Periplus Edition (HK) Ltd. dan Proyek EMDI KMNKLH Jakarta. hal 126-127. 